\section{Terapi Okupasi dalam Kemampuan Menulis Permulaan pada Siswa Autis}

\section{Widia Kusuma Wardani, Sudarsini}

Universitas Negeri Malang Email: widiawardani8@gmail.com

Abstrak: Hambatan belajar siswa autis dalam penelitian ini yaitu dalam menulis permulaan, misalnya menulisnya masih kurang baik, penulisan huruf kurang jelas, belum mengetahui huruf vocal- konsonan. autis menggunakan terapi okupasi.Metode yang digunakan dalam penelitian ini adalah metode Single Subject Reseach (SSR) dengan model desain A-B-A-B. Subjek penelitian menggunakan satu siswa autis kelas 1 di SLB Autis Laboratorium Universitas Negeri Malang. Berdasarkan analisis data diperoleh mean level mulai dari kondisi baseline-1 (A1) sebesar 75,2, pada kondisi intervensi-1 (B1) sebesar 90,8, pada kondisi baseline-2 (A2) sebesar 91,3, dan pada kondisi intervensi-2 (B2) sebesar 91,3. Selain itu, presentase overlap antara kondisi baseline-1 ke kondisi intervensi sebesar $0 \%$. Perhitungan tersebut menyatakan adanya pengaruh variabel bebas (terapi okupasi) terhadap menulis permulaan sebagai target

kunci: autis, menulis permulaan, terapi okupasi

Abstract: Autism is experiencing barriers to learning one of the obstacles to learning autistic students
in writing the beginning, for example writing is still not good, letters written less clear, still don't know vowels and consonants. This study aims to describe about: 1) autistic student ability before being given intervention using occupational therapy, 2) ability of autistic student after being given intervention using occupational therapy, and 3) influence the beginning on writing skill of occupational therapy. This research is done by Single Subject Reseach (SSR) with ABAB design model. Research subjects used one it is obtained the mean level starting from condition of baseline-1 (A1) equal to 75,2 at condition of intervention-1 (B1) equal to 90,8, at condition of baseline-2 (A2) equal to 91,3 , and at condition of intervention-2 (B2) equal to 91,3. In addition, an overlap percentage between baseline-1 conditions to an intervention condition of $0 \%$. The calculation states of occupational therapy to the improvement of writing skills as the target target behavior

Keywords: autism, beginning writing, occupational therapy

Kanner mendeskripsikan bahwa autis mengalami gangguan berbahasa sehingga sulit berinteraksi dengan orang lain, dan ditujukan dengan penguasaan yang tertunda, pembalikan kalimat, dan keinginan yang obsesif untuk mempertahankan keteraturan di dala lingkungan (Handojo, 2001).

Hasdianah (2003) mengungkapkan, "bahwa gangguan perkembangan mempengaruhi beberapa aspek bagaimana anak melihat dunia dan bagaiman belajar melalui pengalamannya. Anak-anak dengan gangguan autistic biasanya kurang dapat merasaka kontak sosial. Mereka cenderung menyendiri dan menghindari kontak dengan orang. Orang dianggap sebagai subjek (benda) bukan subjek yang dapa berinteraksi dan berkomunikasi',

Gangguan pada limbic menyebabkan, "mudah emosi, mudah mengamuk, marah, agresif, menangis, takut pada hal-hal tertentu dan mendadak tertawa, dan perhatiannya terhadap lingkungan terhambat karen dengan orang dampak tertentu, salah satu hambatan belajar siswa autis yaitu dalam menulis permulaan. Dengan adanya perilaku autis tersebut, maka harus segera dilakuka suatu terapi yang sesuai dengan hambatan tersebut, yang penanganan diawali dengan deteksi dini.

Menurut Jamaris (2009) "menulis adalah alat yang digunakan dalam melakukan komunikasi dan mengekspresikan diri dengan cara nonverbal". Menulis juga menggambarkan simbol-simbol sister
yang digunakan untuk keperluan komunikasi.

Dhieni, dkk (2009) mengatakan bahwa, "menulis merupakan salah satu media untuk berkomunikasi, dimana anak dapat menyampaikan makna, ide, pikiran dan perasaannya melalui untaian kata-kata bermakna" Sehingga menulis bukan berarti hanya sekedar membutuhkan tulisan pada media tulis namun juga dapat digunakan sebagai alat untuk menyampaikan nformasi dengan orang lain.

Kemampuan menulis permulaan adala kemampuan dasar yang harus dimiliki anak sebaga tahap awal untuk melangkah menuju tahap menul
Tabel 1 Hasil Kemampuan menulis Permulaan siswa autis Kondisi Baseline-1 (A1)

\begin{tabular}{ll}
\hline Sesi & Nilai (\%) \\
\hline 1 & 77 \\
2 & 74 \\
3 & 75 \\
4 & 75 \\
5 & 75 \\
\hline Jumah & 376 \\
\hline Skor rata-rata & 75,2 \\
\hline
\end{tabular}

abel 2 Hasil Pengukuran Kondisi Intervensi 1 (B1) Kemampuan Menulis Permulaan Pada Siswa Autis Kelas 1

\begin{tabular}{ll}
\hline Sesi & Nilai (\%) \\
\hline 6 & 88 \\
7 & 90 \\
8 & 92 \\
9 & 92 \\
10 & 92 \\
\hline Jumlah & 454 \\
\hline Nilai rata-rata & 90,8 \\
\hline
\end{tabular}

Tabel 3 Hasil Pengukuran Kondisi Baseline-2 (A2) Kemampuan Menulis Permulaan Pada Siswa Autis Kelas 1

\begin{tabular}{ll}
\hline Sesi & Nilai (\%) \\
\hline 11 & 92 \\
12 & 90 \\
13 & 92 \\
\hline Jumlah & 274 \\
\hline Nilai rata-rata & 91,3 \\
\hline
\end{tabular}

emampuan menulis permulaan akan terliha mudah pada anak yang memiliki perkembangan mudah pada anak yang memiliki perkembangan
normal, namun menulis akan menjadi sulit bagi siswa normal, namun menulis akan menjadi sulit bagi

Anak autis memerlukan terapi yang bertujuan untuk membangun kondisi yang lebih baik. Melalui erapi yang rutin dan terpadu, diharapkan hambatan siswa autis dalam montis permulaan kerap berkurang secara bertahap. Terapi juga akan membantu "mengurangi perilaku" anak autis dengan cara menekan gejala-gejala yang dialami menjadi berkurang bahkan hilang, sehingga anak mampu hidup dan berinteraksi dengan masyarakat. Salah satu terapi tersebut adalah terapi okupasi.

Terapi okupasi menurut Sujarwanto (2005) adalah terapi yang berdasar atas occupation atau gerak di dalam suatu pekerjaan, pada kegiatan terapi okupas berusaha/mencapai perbaikan dari kelainan dengan jalan memberikan pekerjaan pada penderita. Terapi okupasi nerupakan perpaduan kegiatan antara seni dan pengetahuan yang mengarahkan anak pada aktivitas selektif. Tujuan utama dari Okupasi Terapi adalah meningkatkan motorik halus dalam meningkatkan kemampuan menulis siswa autis.

Pendapat melalui Amerika Occupation Therapy, (2013) mengemukakan terapi okupasi adalah "suatu perpaduan antara seni dan ilmu pengetahuan untuk menunjukkan jalan dari respon siswa dalam bentuk kegiatan yang sudah diseleksi yang digunakan untuk membantu dan memelihara kesehatan, menanggulangi hambatan, menganalisa tingkah laku, memberikan latihan dan melatih siswa yang mengalami kelainan fisik, mental serta fungsi sosialnya".

Salah satu permasalahan yang ditemukan pada subjek penelitian yaitu masih kurang terlatih pada tahap menulisnya. Subjek sudah dapat mengenal huruf namun huruf vokal saja, tidak dapat melakukan kegiatan menulis secara mandiri. Guru memberikan latihan menulis dengan lembar kerja dengan modalitas kemampuan mengenal huruf. Hal ini diberikan secara berulang-ulang di kelas, akan tetapi belum mendapatkan hasil yang memadai.

Dilihat dari permasalahan tersebut, peneliti bermaksud menggunakan terapi okupasi dalam kegiatan dan tidak terpaku ada pemberian lembarkeria saja namun diterapkan melalui terapi okupasi untuk melatih gerakan tot pensil kedam sutu bentuk gars yang jels.

Dalam hal ini, peneliti akan mengunakan terapi okupasi terhadap kemampuan menulis permulaan siswa

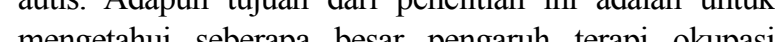
terhadap kempuan menulis permulann siswa SLB autis Laboratorium Universitas Negeri Malang.

\section{METODE}

Desain penelitian ini menggunakan desain A-BA-B. Desain A-B-A-B ini menunjukkan adanya control terhadap variabel bebas yang lebih kuat sehingga hasil penelitian yang menujukan hubungan fungsional antara variabel terikat dan variabel bebas lebih meyakinkan. "Dengan membandingkan dua kondisi baseline sebelum dan sesudah intervensi keyakinan adanya pengaruh intervensi lebih dapat diyakinkan". Dalam penggunaan desain penelitian A-B-A-B ini, dimana A merupakan baseline dan $\mathrm{B}$ merupakan intervensi. Desain A-B-A-B terdiri dari empat tahapan kondisi, yaitu A-1 (baseline 1), B-1 (intervensi 1), A-2 (baseline 2), dan B-2 (intervensi 2).

Prosedur dalam pelaksanaan desain A-B-A-B adalah target behaviour yang diukur secara kontinyu pada kondisi baseline pertama(A-1). Setelah data stabil pada kondisi baseline, intervensi (B-1) diberikan.Pengumpulan data pada kondisi intervensi dilakukan secara kontinyu sampai data mencapai level yang jelas. Setelah itu masing-masing kondisi yaitu baseline kedua (A-2) dan intervensi (B-2) diulang kembali pada subjek yang sama. 
Tabel 4 Hasil Pengukuran Kondisi Intervensi-2 (B2) Kemampuan Menulis Permulaan Pada Siswa Autis Kelas 1

\begin{tabular}{ll}
\hline Sesi & Nilai (\%) \\
\hline 14 & 90 \\
15 & 92 \\
16 & 92 \\
Jumlah & 274 \\
Nilai rata-rata & 91,3 \\
\hline
\end{tabular}

Nilai rata-rata

\section{HASIL DAN PEMBAHASAN}

\section{Hasil}

Langkah pertama dalam pengambilan data adalah melakukan pengukuran kemampuan awal subjek dalam menulis permulaan sebelum diberikan intervensi. Pada kondisi baseline-1 (A1) dilakukan tanpa intervensi untuk mengetahui kemampuan awal subjek. Subjek peneliti dalam kondisi ini hanya diberikan soal tes yang berisi 12 soal mulai dari menulis huruf, suku kata sampai kata dengan tema tubuhku (mengenal nama anggota tubuh).

Adapun data baseline-1 (A1) yang diperoleh dalam penelitian sampai trend data stabil adal sebagai be ikt. Be dis tas tabel 1 di atas dap baseline-1 (A1) kemampuna menulis pera kondis siswa autis kelas 1 yaitu pada sesi perta pondsi mendapatkan nilai sebesar $77 \%$, sedangkan pada kedua nilai yang diperoleh siswa yaitu $74 \%$ pada ses ketiga hinge sesi kelima nilai siswa mulai Pabi sesi $75 \%$. Jika $75 \%$. menulis permulan dengan perolehan sebesar $75,2 \%$

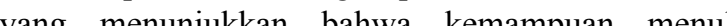
permulan siswa autis dikategrikan rendh, ating a disini butuh penanganan lebih lanjut.

Adapun data kondisi intervensi yang diperoleh dalam penelitan sampai trend stabil adalah sebag berikut. Berdasarkan tabel 2 diatas dapat dijelaska bahwa hasil pengukuran kondisi intervensi I (B1) kelas 1 yaitu pada sesi keenam kondisi mona au nilai sebesar $88 \%$, sedangken pada sesi ketujuh nila yini sebesar $88 \%$, sedangkan pada sesi ketujuh nila


92\%. Jika me sacu pada kriteria kemampun yair permulan, maka dapat diparami bahwa kemapun menulis peruan dengan perles yang menunikkan bahwa kemampuar menth permulan siswa autis dikategorikn tingi, artinya setelah diberikan perlakun (intervensi) kemampun menulis permulan siswa autis mengalami peningkat

Adapaun data yang diperoleh dalam kondisi tabel 3 diatas dijelaskan bahwa hasil kondisi baseline-2
(A2) kemampuan menulis permulaan siswa autis kelas nilai sebesar $92 \%$, sedangkan pada sesi kondisi ini menurun dengan nilai yang diperole yaitu $90 \%$. Pada sesi ketigabelas kondisi ini kembali meningkat dengan nilai yang diperoleh sebesar $92 \%$ Jika mengacu pada kriteria kemampuan menulis permulaan, maka dapat dipahami bahwa kemampua menulis permulaan dengan perolehan skor sebesa 91,3\% yang menunjukkan bahwa kemampuan menulis permulaan siswa autis dikategorikan tinggi.

Adapun data intervensi-2 (B2) yang diperoleh A tabel 4 perolehan data hasil pengukuran kondis intervensi-2 (B2) kemampuan menulis permulaa siswa autis kelas 1 yaitu pada sesi empat belas kondisi ini mendapatkan $90 \%$, sedangkan pada sesi kelima belas sampai sesi keenam belas nilai yang diperoleh mulai meningkat dan stabil yaitu $92 \%$. Jika mengacu pada kriteria kemampuan menulis permulaan, maka dapat dipahami bahwa kemampuan menulis permulaan dengan perolehan skor sebesar 91,3\% yang menunjukkan bahwa kemampuan menulis permulaan siswa autis dikategorikan tinggi, artiny bahwa kemampuan menulis permulaan mengalam peningkatan setelah diberikan perlakuan (intervensi)

Menurut Sunanto (2005), menentukan data overlap data pada kondisi baseline dengan intervensi dilakukan dengan cara : a) Lihat kembali batas bawah dan batas atas pada kondisi baseline. b) Hitung ad berapa data point pada kondisi intervensi yang berada pada rentang kondisi. c) Perolehan pada langkah (b) dibagi dengan banyaknya data point dalam kondisi kemudian dikalikan 100

Data overlap menunjukkan data yang tumpang tindih. Data yang tumpang tindih menunjukkan tidak adanya perubahan pada dua kondisi tersebut. Semakin banyak data tumpang tindih, maka semakin menguat dengan tidak adanya perubahan perilaku subjek pada kedua kondisi.

Berdasarkan data presentase overlap kemampuan menulis permulaan siswa autis kelas 1 dapa digambarkan bahwa mean level pada kondisi baseline-1 80,97, dan batas bawah sebesar 69,42 , sedangkan sko yang diperoleh subjek penelitian pada sesi keenan sebesar $88 \%$, sesi ketujuh sebesar $90 \%$ dan ses kedelapan sampai sesi kesepuluh sebesar $92 \%$, berart tidak terdapat tumpang tindih antar kondisi baseline-1 dan intervensi. Hal ini dapat diyakini bahwa pemberia perlakuan (intervensi) berpengaruh terhadap target perlakuan (intervensi) berpengaruh terhadap target ke kondisi baseline-1 (A-1)

\section{Pembahasan}

Langkah-langkahyang dilakukan dalam penerapan terapi okupasi pada penelitian ini adalah pada kondisi intervensi-1 (BI), siswa diberikan terapi okupas berupa lembar huruf voka putus. Pada lembar tersebut, siswa menebali huruf vokal-konsonan sesuai dengan garis putus-putus pada huruf. Setelah menebalkan huruf, siswa menyebutkan huruf yang ditebali. Pada tahap ini, pemberian lembar huruf vokal-konsonan bergaris putus-putus berjumlah 3 lembar. Terapi okupasi pada penelitian ini memiliki ujuan melatih gerak otot tangan siswa dalam menulis.

Kemampuan awal siswa dalam kemampuan menulis permulaan sebelum diberikan intervensi (perlakuan) pada kondisi baseline-1 (A1) masih rendah. Hal ini ditunjukkan oleh perhitungan analisis data dalam kondisi baseline-1 (A1) dengan mean level sebesar 75,2 kondisi tersebut menunjukkan estimas kecenderungan arah yang menurun karena data pada Kecenderungan stabilitas memperoleh hasil 100\% dengan batas atas sebesar $80,97 \%$ batas bawah sebesar $69,42 \%$. Jejak data menurun karena skor yang diperoleh senakin monurun dari sesi pertam sebesar $77 \%$, sesi kedua sebesar $74 \%$, sesi ketiga level perubahan menunjukkan negatif (-) sebesar -2 ang berarti subjok AM nengalami penurunan dalam kemampuan menulis permulaan.

Dalam hal ini ditunjukkan dengan perhitungan analisis data pada kondisi intervensi-1 (B1) dengan mean level sebesar 90,8 kondisi tersebut menunjukkan estimasi kecenderungan arah yang meningkat karena data kiri lebih rendah dari data kanan. Kecenderungan stabilitas memperoleh $100 \%$ yang berarti data stabil dengan batas atass sebesar $97,7 \%$ dan batas bawah sebesar $83,9 \%$. Jejak data yang meningkat karena skor yang diperoleh stabil mulai dari sesi keenam sebesa $88 \%$, sesi ketujuh sebesar $90 \%$ dan sesi kedelapan sampai sesi kesepuluh memperoleh skor sebesa $92 \%$ dan level perubahan menunjukkan tanda positi (+) sebesar +4 yang berarti subjek AM mengalami peningkatan kemampuan menulis permulaan.

Hal ini ditunjukkan dengan perhitungan analisis data pada kondisi baseline-2 (A2) dengan mean level 91,3 kondisi tersebut menunjukkan estimasi kecenderungan arah yang mendatar karena data pada bagian kiri sama/sejajar dengan data pada bagian kanan. Kecenderungan stabilitas memperoleh hasi dengan batas atas sebesar $98,2 \%$, batas bawah sebesar $84,4 \%$. Jejak data yang mendatar karena skor yang diperoleh subjek relatif sama/sejajar dan mencapai skor maksimal sebesar $92 \%$ dimulai dari sesi kesebelas sampai sesi ketigabelas. Dalam hal ini level perubahan menunjukkan tanda positif $(=)$ sebesar permulaannya tidak mengalam penurunan maupun peningkatan.

Hal ini ditunjukkan dengan perhitungan analisis data dengan mean level 91,3 kondisi tersebut meningkat karena data pada bagian kiri lebih rendah dari pada data pada bagian kanan. Kecenderungan stabilitas $100 \%$ dengan batas atas 97,9 dan batas bawah 84,1 . Jejak data meningkat karena skor yang yang diperoleh stabil dan meningkat dilihat mulai dari sesi keempatbelas sebesar $90 \%$, sesi kelimabelas sebesar $92 \%$, dan sesi keenambelas sebesar $92 \%$ dan level perubahan menunjukkan tanda positif (+) sebesar +2 yang berarti subjek AM mengalami peningkatan kemampuan menulis permulaan

pasi efektif untuk meningkatkan kemampuan menulis permulaan siswa autis. Hal tersebut dapat dilihat dari perolehan data overlap antar kondisi dari baseline-1 (A1) ke kondisi intervensi-2 (B2) adalah $\%$. Susanto,dkk (2005:116) menyatakan bahwa semakin kecil pengaruh overlap semakin baik pengaruh intervensi terhadap target behavior.

\section{KESIMPULAN DAN SARAN}

Kesimpulan

Menulis permulaan dengan komponen menulis huruf (vokal-konsonan), menulis suku kata sampai kata pada kondisi baseline-1 (A1), sebelum diberikan intervensi hasil siswa masuk kedalam kategori cukup rendah, sehingga butuh penanganan khusus dengan diberikan perlakuan (intervensi), setelah diberikan intervensi-1 (B1) mengalami peningkatan.

Penerapan terapi okupasi berpengaruh positif terhadap kemampuan menulis permulaan siswa autis kelas 1, hal ini ditunjukkan dari perolehan hasil presentase overlap dari intervensi ke baseline intervensi pada baseline sehingga dapat disimpulkan bahwa intervensi berpengaruh positif terhadap target behavior.

\section{Saran}

Dari hasil temuan penelitian di lapangan, guru diharapkan dapat menggunakan terapi yang tepat untuk menulis permulaan pada siswa autis dengan cara mendayagunakan semua indera yang ada. Dengan terapi okupasi dalam menulis permulaan dapat diterapkan untuk membantu siswa dalam meningkatkan (an menulis permulaan dan juga dapat melatih gerak otot tangan sehingga gerakan tangan tidak kaku ketika menulis.

Mahasiswa jurusan Pendidikan Luar Biasa diharapkan dapat mempelajari lebih lanjut tentang terapi okupasi sehingga dapat diterapkan pada proses dan sesuai dengan karateristik dai mang serupa siswa. 
Peneliti selanjutnya diharapkan dapat mengembangkan penelitian dengan menggunakan terapi okupasi pada subjek dengan karakteristik yang berbeda atau dengan target behavior yang berbeda sehingga dapat memberikan pengetahuan yang lebih luas.

\section{DAFTAR RUJUKAN}

American Psychiatric Association. (2013). Diagnostic and Statistical Manual of Mental Disorder, Washington $\quad D C$ : American Psychiatric Association

Dhieni, N,dkk. (2009). Materi Pokok Metode Pengembangan Bahasa. Jakarta: Universitas Terbuka

Handojo, (2001). Autisma. Jakarta Barat: PT. Bhuana Ilmu Populer
Hasdianah, (2003). Autis Pada Anak: Pencegahan Perawatan dan Pengobatan. Yogyakarta: Noha Medika

Jamaris, M, (2009). Kesulitan Belajar (Perspektif, Asesmen, dan Penanggulangannya). Bogor: Ghalia Indonesia

Noor,S. (2000). Permasalahan Psikologis Seputar Penyandang Autisme. (Makalah) Seminar Deteksi Dan Intervensi Dini Autisme Pusat Pengkajian dan Pengamatan Tumbuh Kembang Anak. Pena Leluasa, AMSA FK UGM. Yogyakarta

Sujarwanto.( 2005). Terapi Okupasi Untuk Anak Berkebutuhan Khusus. Jakarta: Debdikbud

Sunanto, dkk.(2005).PengantarPenelitian Pendidikan Dengan Subjek Tunggal. Tsakuba:CRICED University of Tsakuba 